\title{
THE BLIND SPOTS OF SECULARIZATION
}

\author{
A qualitative approach to the study of \\ antisemitism in Spain ${ }^{1}$
}

\section{Alejandro Baer and Paula López}

ABSTRACT: According to several international surveys Spain is among the western countries with the most negative views of Jews. While quantitative data on the topic accumulates, there is a significant lack of interpretative approaches that might explain the particular Spanish case. This paper presents the background, methodology and major results of a discussion group-based study on antisemitism, which was conducted in Spain in the autumn of 2009. The study identifies and locates in different socio-economic and ideological milieus the range of stereotypical discourses on Jews, Judaism and the Arab-Israeli conflict in Spain. Analysis of the group meetings shows that, despite growing secularization in Spanish society, the central explanatory variable for persisting and resurging antisemitism in this country is still religion in a broad cultural sense.

Key words: antisemitism; Spain; Jews; secularization; Muslims; qualitative methodology

\section{Introduction}

A number of recently performed public opinion surveys have revealed that Spain has one of the highest levels of antisemitism in Europe. The studies

1. We thank Hubert Knoblauch and Bernt Schnettler for the critical feedback and helpful comments given at the sociological research Kolloqiums of the TU Berlin and the University of Bayreuth. We also wish to thank the blind reviewers for insightful feedback as well as the editors of this volume, Robert Fine and Christine Achinger, for their comments, amendments and patience. We are grateful to Eric Heuberger for his careful proofreading of the English manuscript. Special thanks go to Patricio Pedraza. Without his professional commitment and his expertise conducting group discussions this study would never have been accomplished. 


\section{EUROPEAN SOCIETIES}

undertaken by the Anti-Defamation League (ADL) concerning attitudes towards Jews, Israel and the Palestinian-Israeli conflict in 10 European countries, asked people to grade their agreement with a number of antiJewish statements. The Spanish replies stood out among all other countries for nearly all the categories. ${ }^{2}$ A 2008 survey by the Pew Research Center found 46 percent of the Spanish rating Jews unfavorably. While unfavorable views of Jews - and Muslims - are on the rise in all European countries surveyed, Spain surpasses them all by a wide margin.

The framework of the statements, the standardized testing procedures and the near ubiquitous use of telephone interviewing adopted in these studies raise a large number of questions concerning the aptness of the instrument employed for measuring such a complex phenomenon as antisemitism. ${ }^{3}$ However, the results obtained from these surveys have the undeniable virtue of having raised the profile of the discussion about antiJewish sentiment in today's Spain, where the vast majority of researchers, politicians, social figures and government institutions believe that antiJewish sentiment does not in fact exist. The present empirical research was undertaken in this context at the behest of Casa Sefarad-Israel, a public institution that is dependent on the Spanish Government, which decided to finance its own sociological study. This provided an opportunity to deepen the scope of the analysis and to determine whether there is a Spanish exceptionalism concerning antisemitism.

This paper presents the background, methods and major results of a discussion group-based qualitative study on antisemitism, which was conducted in Spain in 2009.

\section{Overview and research questions}

The theoretical framework and research questions of this study draw on a number of scholarly works on antisemitism in Spain, which use mostly historical approaches, as well as some recent studies on the depiction of Israel and the Israeli-Arab conflict in the Spanish media.

2. For example, in the last survey undertaken in 2009,74 percent of those interviewed answered 'fairly certain' to the statement: 'Jews enjoy too much power in international financial markets' See: Anti-Defamation League, Attitudes Toward Jews in Seven European Countries, February 2009.http://www.adl.org/Public\%20ADL\%20Antisemitism\%20Presentation\%20February\%202009\%20_3_.pdf

3. Only questionnaires carried out in a standardized way will produce comparable data across different countries. But the question arises whether one should suppose that the categories used in survey studies are adequate for the comparative study of antisemitic opinions and attitudes. In addition to being elusive, they are marked by their own homegrown character. 
Studies on antisemitism by historians underscore the persistence of attitudes connected to casticismo [Spanish traditionalism] and the enduring link between the 'Jewish question' and Spanish national identity (Alvarez Chillida 2002; Alvarez Chillida and Izquierdo 2007; Rohr 2007). ${ }^{4}$ In this sense, antisemitic motives of a religious nature (Jews as Christ-killers, accusations of ritual crimes and profanation of Christian symbols, etc.) did not disappear following the expulsion of the Jews from Spain in the fifteenth century but rather remained firmly anchored in the cultural memory. Modern anti-Jewish propaganda added a discourse of its own to the older one. It underwent a re-birth during the Second Republic (19311936) particularly with the attribution of an international Jewish conspiracy and the myth of Reconquista. ${ }^{5}$ Modern antisemitism contained elements of nationalist identity politics, unified around notions of religion and national purity, in the face of a Socialist or Liberal internationalism coded as 'Jewish' or even directly identified with Jews (Krauze 2005; Rohr 2007). Our study tries to find out whether negative perceptions of Jews were inherited from older religiously rooted stereotypes, since the country is still by tradition and culture predominantly catholic, ${ }^{6}$ and whether this type of thinking, hitherto useful to reduce complexities and constitute an 'us' in terms of national characteristics, religious identity or social formations, continues to play a role in contemporary Spain.

Philologists and social anthropologists have pointed out the long and persistent roots of tales and traditions with anti-Jewish elements in Spain. Centuries of casticismo left a deep anti-Jewish mark on Spanish popular culture, closely linked to anti-Moorish sentiment (Pedrosa 2007). Today in Spanish languages, Castilian, Catalan and Galician, calling someone a judio can refer to anyone who is accused of usurious practices (Alvarez Chillida 2002). 'Ir a matar a judios' or 'going to kill Jews' is still used, and means

4. Casticismo is a literary, cultural and ideological style linked to reactionary thinking. It is an assertion of traditionalism, expressed in terms of culture, religion, life style, attitudes, speech or political and social organization. It is perceived by traditionalists as behavior proper to their breeding (casta), seen not as a question of race or ethnicity but as a reflection of national Spanish character (see Stallaert 1998).

5. According to Isabel Rohr, this political myth was developed in the nineteenth century 'as Spanish intellectuals, traumatized by the loss of Spain's American colonies, pondered their national identity and history'. The idea was that 'there existed an eternal Catholic-Spanish essence, Hispanidad, born in the Visigoth time and resurrected during the centuries-long fight to capture Spain back from the Moors, the Reconquista' (Rohr 2007: 4).

6. The path to secularization in Spain is reflected dramatically in individual religious practices, although not as much in religious identification. According to the survey barometer of the Centro de Investigaciones Sociológicas (CIS), December 2006, 77.1 percent of Spaniards still define themselves as Catholics. 


\section{EUROPEAN SOCIETIES}

going off to drink wine and engage in noisy behavior on Holy Thursday before Easter. Many utterances related to Jews still contain negative connotations in the Spanish language. A source of sociological information is provided by dictionaries, which continue to list many of these antisemitic terms, or terms which contain antisemitic explanations. For example, a judiada is defined as a 'bad action which was tendentiously considered as Jewish behaviour' (Dictionary of the Real Academia Española - DRAE, 2005). Sinagoga, according to the same source is 'to gather together for an illegal undertaking', while hebreo is defined as a merchant and one of the accepted meanings of judio is a 'greedy person' (Maria Moliner). It is also true that an antisemite is defined as a person who is an 'enemy of the Hebrew race, of their culture or their influence' (DRAE, 2005 our emphasis). Our study attempted to find out the extent to which the use of aphorisms and antisemitic language in dictionaries reflects perceptions about Jews in today's Spain, and whether they are a factor exciting antisemitic opinion or just semantic leftovers from a nearly extinct religious culture due to disappear with the passing of older generations.

A series of studies undertaken over the last decade have looked at representations of Israel and the Middle East conflict more generally in the Spanish media. Israel and the conflicts in which it is embroiled are the main elements associated with 'Jewishness' in Spain today. Some of these studies are based on content and discourse analysis (Wahnón 2005; Baer and López 2010), and others offer valuable reflections by Spanish journalists (Albiac 2004; Villatoro 2004; Culla 2005; Gabriel 2010). These studies have maintained that there is a specifically Spanish pattern, based on a combination of characteristics each of which taken on its own may not be exclusive to the Spanish media. This includes: (i) a tendency to proArab Manichean thinking when discussing the parties to the conflict, (ii) the overlap of anti-Zionist and anti-American rhetoric ${ }^{7}$ especially prevalent in the liberal press but not absent in the conservative media, and (iii) the use of stereotypes rooted in religious antisemitism in the portrayal of Israelis and the State of Israel especially in opinion columns and editorial cartoons. What does constitute a specifically Spanish characteristic is the adoption of these discourses across a broad swathe of the political spectrum. Our study attempted to establish the extent to which there is a link between published opinion and public opinion and the level of influence on the general population of stereotyped and occasionally unabashed antisemitic messages derived from the Middle East conflict.

7. According to the Transatlantic Trends study of 2004, in Spain hostile sentiments towards the United States are the most pronounced in Europe. 


\section{Data collection: the discussion group}

Spain presents a case of antisemitism without Jews (Jews in Spain represent less than 0.1 percent of the population). Basically, anti-Jewish perceptions cannot be related to objective considerations, such as friction between actual social groups, but rather to imaginary or abstract Jews. To investigate the makeup of this abstract and imagined Jew in contemporary Spain and to uncover the roots of this construction, the discussion group seemed to provide the most suitable type of research method. ${ }^{8}$

We understand the discussion group as device for producing discourses that simulate a conversation, where the visions and values of the participants refer to a system of common signifiers. What it is said during 'group discourse' is more than a simple series of statements. What is enunciated is a socially coherent discursive praxis. The participants carry with them the indelible imprint of the social environment to which they belong. The information obtained from the group participating in the discussion is a reconstruction of the structures of meaning re-created by the social interaction. The conversation of the group has a logic which reproduces the social bond and the collective element (León Barrios 2007).

Technically speaking, this research method consists of bringing together individuals for a 'group discussion' in a meeting whose duration is between 1.5 and 2 hours, and is led by a moderator who outlines the topics to be discussed. Talk is free and the proposed topic is discussed around a table in the most neutral setting possible. The size of the group varies from seven to nine people. These are not real groups but rather groups with an identical structure. Participants are of a similar age, share the same life strata, and have a similar socialization with regard to education, professional track, area of residence, etc. The individual shares and displays a native or vernacular language in the group dynamic and a

8. The discussion group is a qualitative research technique anchored in two theoretical approaches with substantial epistemological differences. The North American version, best known today as the focus group, was developed through the use of group interview techniques as an instrument of social and psychotherapy-based analysis. It was undertaken in the United States in the 1930s and 1940s by Robert K. Merton, M. Fiske and Patricia L. Kendall. The other version is European, in particular Spanish, the work of Jesús Ibáñez (1979). Known as the 'discussion group', its theoretical framework combines linguistics, semiotics, and structuralism. As a research method it has been developed by Enrique Martin Criado (1997), who added an interactionist dimension to the analysis. It is nowadays widely employed for the empirical analysis of daily social life (see Valles and Baer 2005). Research on antisemitism with this type of methodology can be traced back to the 'Group experiments' conducted by Friedrich Pollock at the Frankfurter Institut für Sozialforschung in 1950/51 (Pollock and Adorno 2011). 


\section{EUROPEAN SOCIETIES}

'group discourse mode' develops in relation to the topics established by the moderator.

In accordance with the purpose of the study, our intention was to broach a discussion about Jews, Judaism and Israel, in order to explore the specific workings of antisemitism in different social environments. The purpose is not to learn about individual opinions and the research is not about reproducing personal discourses, such as is common in the interview mode. The methodology is group-centered and focuses on the collective patterns of meaning and interpretation that emerge through the interaction. Far from being a psychology of the antisemite, our study falls into the category of sociology of (antisemitic) communication and knowledge. It looks into antisemitic talk and considers the possibility of antisemitic opinion as a cultural code linked to a broader field of political, religious or social positioning (Volkov 2000). The analysis of group discourse should then bring us closer to understanding the use of certain antisemitic semantics in various environments and social milieus, while also showing their respective intensity and relevance.

\section{Sampling and group composition}

The group meetings were designed according to the assumption that there can be significant differences between various expressions of the antisemitic phenomenon in Spain. We selected groups that differ according to their social strata, political identification or religious practice. Age has been deployed as a variable to integrate a diachronic perspective into the study. The types making up the canon in the history of antisemitism - religious, modern/racial, and political or 'new' antisemitism - served as background hypotheses in the composition of the groups. The groups were, therefore, defined according to a cultural/religious axis (classical anti-Judaism), a social class axis (modern antisemitism) and a political axis composed of left/right wing political positions (anti-Zionism and new antisemitism). ${ }^{9}$

Needless to say, our sampling method is of a theoretical, not statistical, nature. While clearly not covering the entire scope of milieus and lifeworlds, we aimed to have a structural sample of the Spanish, nonmigrant population. We consciously excluded a cohort from our sample

9. To the extent that modern antisemitism is expressed in fundamentally anti-liberal and anti-modern terms, social class is obviously only one variable among others, closely correlated to political and religious aspects, and would require more detailed explanation (see Goldberg 2008). 
positioned on the extreme right since discourses in this environment are more clear-cut and generally known (Cobo and Ortega 2008) (see Figure 1).

The RG1 group comprises participants from the $65+$ age group from rural populations, which reflects the attempt to learn about the persistence of traditional religious antisemitism. The selection of RG2, business executives, is designed to test the hypothesis of modern/economic antisemitic discourse. They belong to the sphere of commerce and finance, spheres often defined as 'Jewish' with attributes of abstraction, mobility, intangibility and rootlessness. This group only includes men because women are a minority among Spain's business executives. RG3 corresponds to urban areas witnessing strong economic growth in eastern Spain active in terms of religious (catholic) and political (conservative) identity. They are all voters of the Partido Popular and active members of the Catholic Church. RG4 is a group at the center with respect to politics (non-voters or those voting center options such as Convergencia i Unio, PSUC), young, educated (all university students) and living in Barcelona, where there is a much weaker national identification with the Spanish State. RG5 is a group whose (leftist) political identity is strong. These are activist and strongly ideological youth who belong to social movements and associations, living in the working class periphery of Madrid and highly self-defined in regard to class and activist orientation. RG6 is a

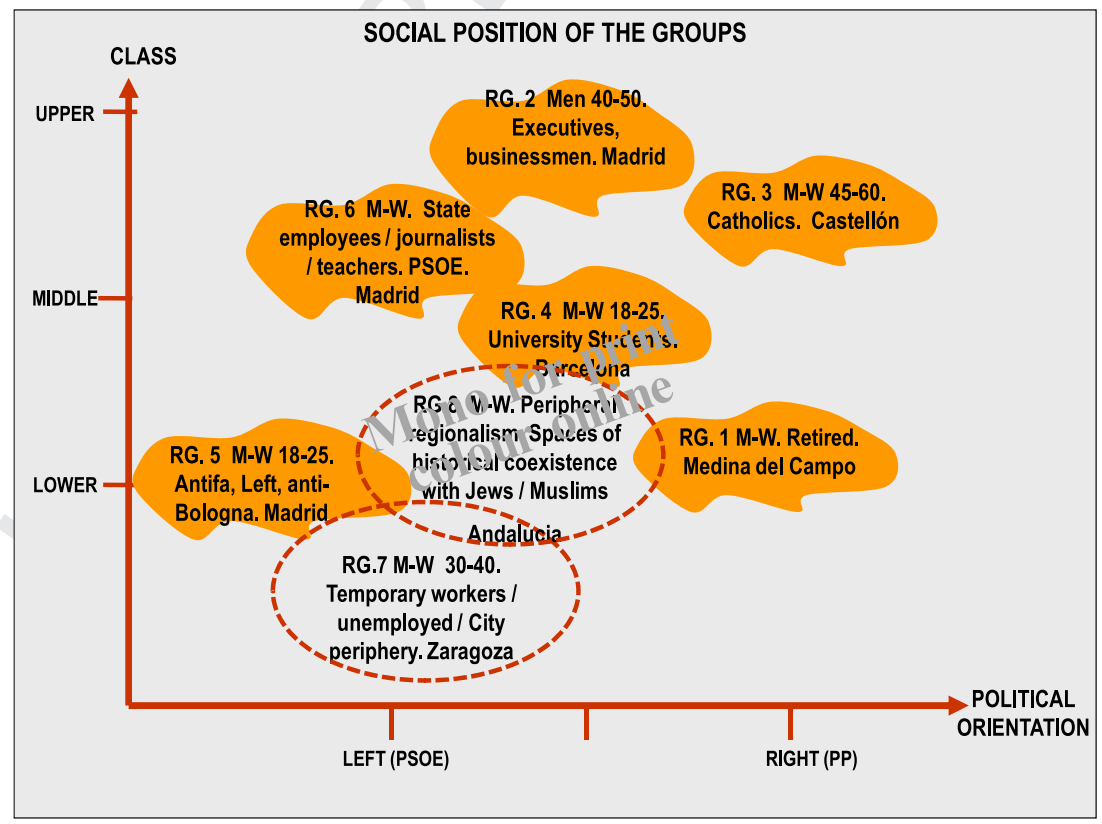

Figure 1. $X X X$ 


\section{EUROPEAN SOCIETIES}

progressive group, voting for the Partido Socialista, middle-aged and already professionally established in areas such as education, journalism, and state agencies. It is a group that belongs to the liberal mainstream. ${ }^{10}$ The individuals for each group meeting were contacted through a third party, 'contactadores' who selected people who did not know each other and matched the group profile criteria established by the research team.

A series of exhaustive in-depth exploratory interviews were carried out in advance with individuals who correspond to the various group profiles. The purpose of this was to sort out the various discourses, to refine the discussion guidelines and to make the moderator familiar with the topic of research.

\section{The group dynamics}

The discussion group attempts to provide a space for communication which progresses in the manner of a normal conversation. The selection of the initial topic introduced by the moderator is an important factor designed to be open and tangible enough to provoke the fluid and spontaneous exchange. This was not easy to achieve. Jesús Ibáñez, paraphrasing Heisenberg's famous quote, wrote that 'all the various approaches are good, but they involve certain consequences - they produce certain effects - while others lead to yet other effects; the researcher must quite simply place himself in a position to calculate the effects resulting from his decisions' (1979: 262). ${ }^{11}$ We decided that the moderator would provide the group with an initial starter topic indirectly tied to the actual research topic:

...We are conducting a study on religious minorities in Spain: Muslims, Islam, Jews, Judaism, Protestants, Protestantism and we would like to know your opinion, what your current thinking is on this subject, on these religions and the people of those faiths...

This initial starter topic concerning 'religious minorities' reflected a methodological choice: not to go straight into the specific topic of research whose strong potential for reactivity was foreseeable. It also contained a

10. Two groups which were part of our initial conception were not included due to budgetary limits. RG7 included the unemployed and sub-employed living in the urban periphery. RG8 was conceived in order to explore the possible survival of a coexistence heritage - the myth of 'Sefarad' and of the three cultures - in a location (notably Andalusia) where this conception is widespread.

11. 'What we observe is not nature itself but nature exposed to our method of questioning' (Northrop 1962: 17). 
theoretical implication since we were interested in exploring the image of the Jew and how it appears in relation to various portrayals of the 'other' in a cultural system which still revolves around the identity-difference dichotomy. The homogeneity of the Spanish population in the perception of an 'us' (Catholic) made it possible to entertain this oblique focus on minorities of so-called notorio arraigo (well known and rooted origin): Muslims, Protestants and Jews, who precisely due to their roots (and uprooting) have come to compose the 'other' in Spain. They are seen as culturally and religiously different, antithetical and hostile in their social and political make-up. ${ }^{12}$

At first, the work of the moderator remained purposefully nondirective, in order to allow for spontaneity and frankness and to ensure that the group would persist. But in the second phase the moderator used a more direct form of questioning and a more detailed exploration of the thematic: Judaism as a religion, Judaism in Spain and in the world, and the conflict in the Middle East. In this phase, editorial cartoons from the Spanish press concerning the conflict between Israel and Palestine were also used as a means of projection (see for example Figure 3). This combination, as we shall see, made it possible to reconstruct the constitutive logic underlying the production of a discourse on the subject of the Jew, Judaism and Israel and to observe in which dimensions and areas antisemitism was evident. The group dynamics were maintained for periods of between 1.45 and 2 hours.

\section{The logic underlying the production of an antisemitic discourse}

The first result which we wish to discuss is directly taken from the initial starter topic which referred to three religious minorities, Muslim, Jewish and Protestant. Although Jews were named as such in this introduction, they hardly took up the whole discussion space during the open moderation phase. At first, Muslims generally constituted the focus of conversation. The group dynamic revolved around the problem of immigration (although there were also references to Christian migrant groups in Spain such as Romanians and South Americans), integration and cultural differences. It was only during the directed phase of moderation, when the moderator explicitly asked about the subject of this study, that Jews, Judaism and Israel became subjects of discourses charged with emotive weight and political intensity.

12. As indicated by Jose Manuel Pedrosa, 'the Spanish tradition of anti-Judaism is closely related to similar traditions which have been wielded against other people' (2007: 32). 


\section{EUROPEAN SOCIETIES}

The growing secularization of Spanish society in terms of individual religious praxis, State-Church relations and especially the erosion of cultural/religious homogeneity through recent settlement of a noncatholic migrant population (Agote and Santiago 2005) is one of the milestones marking the perception and construction of images and discourses on minorities (Muslims and Jews). On the one hand, there is an ambivalent identification with Muslims, who seem to reflect an element of the Spanish past. This was expressed in the group dynamics in terms of 'we used to be like that too', meaning religious, male-chauvinist, backward and poor. It involves a paternalist vision not devoid of racist elements (the Muslim as the 'good savage' unpolluted by modernity), which exists both among conservative and more progressive groups. On the other hand, when the moderator brought it up, there was a clear counter-identification in opposition to Judaism and the Jews. In relation to the Jews, no identification was expressed; instead there was a feeling of unease from entering uncharted territory (see Figure 2).

'- The Muslims... they are in the middle-ages... they are there (points with his finger to one end of the table), we are here... (points to the middle of the table) Please place the fews over there... they get way ahead' (points his finger beyond the table). (RG3)

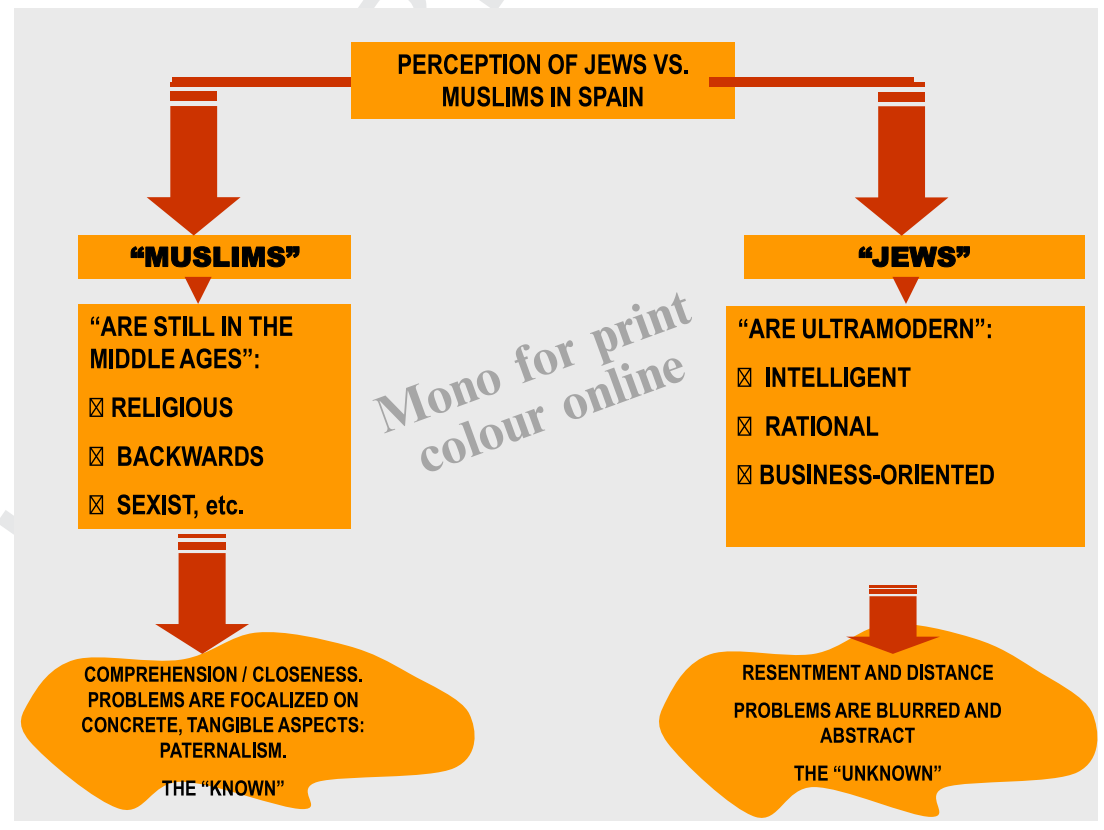

Figure 2. $X X X$ 
It looks like there were negative stereotypes for Muslims and positive stereotypes for Jews in these statements. But in this particular context these perceptions can be interpreted as a worldview that takes a hostile, or at least very ambivalent, outlook on the values of modernization: the mercantile world, commerce and industry. ${ }^{13}$ Anti-Americanism and antisemitism, not strictly on religious grounds, are in fact here two branches of the same tree: the rejection of modern western liberal values, which in Hispanic cultures has been particularly pronounced. In opposition to these values are the mysticism, heroism, and so-called chivalrous values of the old regime. The figure of the Jew in general and the State of Israel in particular are perceived and presented as the incarnation of the values of the modern mercantile world. This is the common thread which ties together the confrontation of both left and right with the model of liberal democracy. Against the 'imaginary Jews' is pitted an 'imaginary Arab', a noble savage uncontaminated by the spirit of modern economics (Villatoro 2004).

It must be pointed out that in the context of the problem of integration and assimilation of migrant minorities (a vector of communication of tremendous importance in all the meetings of the groups), invisibility is considered a virtue (they are not a bother, it is as if they were absent). 'If you don't see them' it follows that they have managed to adapt and integrate. The Protestant minority are mentioned as an example in contraposition to the Muslims whose public visibility (hijab, minarets, etc.) tends to be seen as an attack on the ideal status of assimilationist integration. The need for homogeneity and normalization places a dominant emphasis on an assigned model of ideal integration in Spain, associated with invisibility and the impossibility of recognizing cultural/ religious differences. This is one of the significant observations made in this study which, though surpassing the objectives of the study, have specific implications for the problem of antisemitism. The Jewish minority in Spain (few in number, indistinguishable and therefore 'invisible') would seem to match perfectly the requirement and demand imposed by the collective imagination of the Spanish with regard to integration and respect. But in the case of the Jews, non-visibility or absence of differentiation carries an ambivalence which turns out to be very significant. Compliance with this condition of invisibility, as a prior acceptance of Jews, is accompanied by the production of fantasies and suspicions regarding their social invisibility. The problem in relation to Jews is that they cannot be

13. The crisis of the ancien régime began and ended much later in Spain than in France. The reasons for this delay lie in Spain's belated capitalist development and the peripheral character of its industrial and financial development. There was also no nationally powerful bourgeoisie (see Perez Agote 2010: 227). 


\section{EUROPEAN SOCIETIES}

identified and the inability to identify them becomes part of the stereotype:

'Behind the scenes, from behind they pull all the strings...'(RG4). 'Well you see, we never really know... There are fems everymhere' (RG6). 'They plot... and you don't even know it'. (RG3).

In the group dynamics the invisibility of the Jews in Spain ties in with well-established, antisemitic motifs - the attribution of secrecy, hiding under different flags, concealing actions in order to advance special interests, etc. - which are mostly employed in the conspiratorial reading of global events from financial crises to wars.

The American banks are fewish, man, you know I mean just look at what the fews set up...' (RG2). 'They've managed to dominate political power in the United States. Rockefeller did what he did'. 'They've got the world by the rope...' (RG3). 'The Twin Towers thing... Fifty thousand people can fit in both tomers, and the fews who were working there had time to escape' (RG6).

In some ways the absence of empirical experience of actual Jews, Spanish Jews, leads to a discussion of Jews conducted by way of images, most of which are unequivocally antisemitic. These images are firmly established in the collective imagination or in the cultural memory (Assmann 1994). ${ }^{14}$ These discourses are reproduced in different groups and contrary to expectations there is little to distinguish the left from the right. What we have identified is a gradual decline of religion-based antisemitic motifs (among older people in small or medium scale rural settings, among the lower middle class). 'The fews are bad ...' (RG1); and at the same time the repetition and rationalization of an economics- or politics-based antisemitic discourse (among youth and adults, urban, middle to lower middle class, conservative and progressive). 'Behind this [grabbing a can of coke] are the Jems' (RG6).

It is notable that the interpretative framework for perceiving Jews and Muslims can also be applied to the Palestine-Israel conflict whose centrality, based on its hyper-visibility and special place in the Spanish media, is present in the discourses of all groups with remarkable intensity. Palestine is the object of the paternalistic outlook toward Muslims and the conflict is perceived from a Manichean perspective and a cosmology

14. In some isolated cases, where the participant had actual experience of Jews, there is an immediate questioning of the use of these negative stereotypes. This occurred in RG2 (corporate) and in RG5 (students from Barcelona). In both cases an important element of reflectivity was introduced into the group dynamic. 
impregnated with Catholic culture. We can identify here again the ambivalence with respect to Spanish modernization we mentioned above: the Arab as the 'good savage' who represents our past. This framework assigns all available roles in advance. Palestine, as an antagonist to Israel, can only be an innocent victim and Israel can only be guilty.

We need to support the meak side. It's not a left-ming thing. It's just human (RG1).

In the editorial cartoons about the conflict (see Figure 3 ) used by the moderator in the group dynamic, numerous condensed versions of this discourse were expressed across all groups.

There was no discussion in the groups with regards to representations of the Star of David made of concentration camp wire, or the flag of the United States where the stars are now Stars of David. When we used cartoons as a projective technique, most group participants saw their ideas about the conflict reflected in them and did not identify any antisemitic trait.

The Holocaust was also the subject of discussions in group dynamics and always emerged spontaneously. In historical terms the Jewish specificity of the genocide is usually questioned by the participants (what about the other victims?) and Holocaust remembrance is usually perceived as specifically 'Jewish' and distant. The transnationalisation of Holocaust culture with universal moral and political appeal, the effects of which are also felt in Spain (Baer 2011; Baer and Schnettler 2011), does not actually heighten sensitivity towards the issue of antisemitism; it undermines it. The theme of the (former) victims as (present)

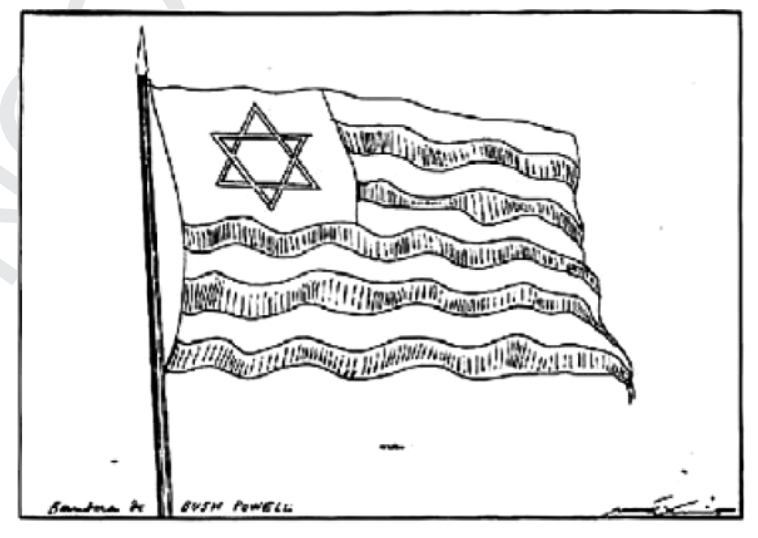

El Pais 18/04/2002

Figure 3. $X X X$ 


\section{EUROPEAN SOCIETIES}

perpetrators in Israeli uniform, which popped up frequently in the groups, denies the possibility of any sustained memory of the Holocaust. It is in turn recycled in a number of negative stereotypes: hypersensitivity and manipulation through victimization, political (Zionist) instrumentalization and mercantile gain (compensations).

'These people are here doing all this stuff and then they go to the Holocaust Museum and there is all this moaning, and then they go and continue their target practice...' (RG5).

W: 'What I understand is that they continue getting money from Germany. That's why it's become such a huge thing. But in the case of the Poles, the others, and the others. Those guys are real quiet'.

M: 'What they don't understand is that what was done to them, that's what they're doing to the Palestinians. I'm not saying the Palestinians are saints, because they're not. Because from time to time they shoot a rocket, like those firemorks at a fair, which don't kill anyone and don't do anything'. (...)

$W$ : 'On top of it you're supposed to say: 'Oh my, so many fems have died'. And the Palestinians...' (RG1).

\section{Some conclusions from the study}

The analysis of the discussion groups provided some evidence concerning the initial hypothesis. While the semantics of each group is characterized by its own particular intensity, relevance and delivery, there remains the notable fact of a cross-cutting and overlapping commonality between them with regard to content and patterns of interpretation.

First we need to stress the particular difficulty posed by the Spanish case for the framework of so-called 'new antisemitism' or 'secondary antisemitism' theories, which since 2000 and in the context of the ArabIsraeli conflict have attempted to interpret the resurgence of antisemitism in Europe. Unlike in France, antisemitism in Spain cannot be explained by the growth of Muslim antisemitism (a minority phenomenon in Spain because of the weak political voice of first generation immigration) nor can demonization of Israel be understood as an effect of a particular interpretation of the memory of the Holocaust (Finkielkraut 2004). There is no such 'deterritorialisation of the Intifada' (Beck 2004) in Spain, nor has Israel served the Spanish as a vessel into which to project all that is bad in European history, i.e., the Jewish state as embodying an extreme, aggressive, racially exclusive nationalism (Ottolenghi 2005). The marginal position of Spain in European history obviates such an explanation. 
While current antisemitism in Spain is also connected to the Middle East conflict and to anti-Israel sentiments, its cultural and ideological composition is significantly different. We argue that the central explanatory variable for antisemitism in Spain is still religion in a broad cultural sense, and in particular the aspect of religion that Charles Glock (1962) has identified as its 'consequential' dimension. ${ }^{15}$ Analysis of the group meetings has shown that antisemitic hostility is expressed in three types of discourse: religious, economic and political. While these are more or less defining for each respective group, the religious element is exceptional, acting as a matrix for all the others and encompassing Israel-related antisemitism.

Antisemitic discourse based on religious socialization has as its central symbol the myth of deicide, which produces a number of values, attitudes and behaviors. It is one of the key symbolic elements of the Catholic religion. It characterizes the essence of Jews as a people by reference to the killing of the son of God. If when you want to say someone is bad, you say he/she is Jewish, this naming of 'badness' as Jewish presupposes the permanent enactment of the founding myth of Christianity. The repetition of this representation of Jews rests on the same processes of socialization and education which buttress the ceremonial reproduction of the myth. These religious images also contain a number of profane stereotypes which are part of a wider social representation of Jews: the intelligence of Jews, their concomitant craftiness and their diligence in work. The current conflict between Palestinians and Israelis has come to represent the essence of this religious culture. The conflict is constituted as a secular reproduction of a sacred myth based on religious stereotypes: 'because of the may they are, because with the Jems it's 'an eye for an eye', they manifest ill-will, cruelty and vengeance in their basic social values and relations with other peoples. It may appear that this type of discourse is retreating due to strong forces of secularization and modernization. However, the obvious weakening of the Catholic religion as a focus for organized practices has not automatically led to a loss of its symbolic functions. ${ }^{16}$ The secularization of antisemitic images does not erase their religious origin.

This deep-rooted Catholic substratum in Spanish culture explains why we find the religious dimension of antisemitism underlying the other two

15. Glock defines this dimension in terms of the consequences of belief, religious praxis and religious experience on the everyday life of individuals (Starck and Glock 1970: 16). Here we explore the traces of Catholicism in the habitus of individuals, a system of dispositions 'whose limits are set by the historically and socially situated conditions of its production' (Bourdieu 1990: 55).

16. See, for example, the condensed discourse of our group of Madrid progressives: 'and obviously, most of us are Catholics. As I've said, 'me are' because that's our tradition. In fact, I'm also an atheist' (RG6). 


\section{EUROPEAN SOCIETIES}

dimensions we have identified. ${ }^{17}$ Here it is necessary to point to the exception of RG4, the group of young students from Barcelona, who articulated far fewer antisemitic clichés and more reflective positions with regard to the Palestine-Israel conflict. It was also this group which showed a high degree of remoteness and ignorance with regard to religion and the Church. In this respect we may say that 'exculturation' (Hervieu-Léger 1993), the process by which culture loses its Catholic roots, has an influence on the employment of antisemitic interpretations of reality (ideologemes).

The economically based antisemitic discourse is characterized by a reduction of the Jew and Jewishness to economic power and its translation into a capacity to influence and manipulate reality. This discourse of economic power is also rooted in the Spanish cultural amalgam. Thus the rhetorical stereotypes linked to usury and to Jews' relation to commerce are being updated through images such as 'they control money' or 'they control the large companies'. This economic dimension may seem at first sight disentangled from sacred values, the foundational myth which ushers in the accusation of malice, but it is linked to power in the profane world and the influence money brings: 'that's what I say about the fews, that the biggest countries, you know, which have so much money through their companies, they don't say anything to them and they do what they mant, right?' The discourse associating Jews with economic power continues to depict them as a source of danger and malice. It is expressed across a broad ideological spectrum, from conservative groups (as indicated) to more progressive-minded professionals.

In the politics-based antisemitic discourse, the dominant lens through which Jews and Judaism are perceived is that of the Palestine-Israel conflict. The experience of the conflict boils down to the consummate production and intensification of feelings: ${ }^{18}$ 'they have doors in the wall and when it rains they close the sluice gates to dromn them' (collective homicides using inhuman techniques); 'they shoot at mater tanks so there's no water in the houses' (targeting the civilian population); '[Palestinians] have to have grids in the streets so that the garbage they throw on them doesn't fall on them'

17. We would agree with scholars who interpret antisemitism in terms of cultural theory as a function of Christianity. William Brustein (2003) also distinguishes between religious, economic and political dimensions of antisemitic discourse (adding a fourth racial dimension). His answer to the persistence of antisemitism is the primacy of Judaism as the core belief system through which and against which the central cultural/religious motors of European identity are defined.

18. There is a growing emphasis on feelings over reason, and to the detriment of the latter, emanating from Palestine Solidarity campaigns in Spain. See, for instance, a recent video in support of a second flotilla to break the Gaza blockade with the title 'Y tú qué sientes' (What do you feel?): http://www.youtube.com/watch? $\mathrm{v}=\mathrm{WH} 04 \mathrm{~W} 38 \mathrm{WBDQ}$. 
(humiliating, inhuman and vexing treatment); Jews are seen as 'A permanent source of conflict everywhere'. The conflict reactivates images and sentiments as powerful as older myths linked to religious rhetoric. Hate, vengeance, impunity are the basic semantics through which the position of Israel is assessed.

Consensus concerning the problematic nature of the state of Israel and its lack of political and historical legitimacy unites all but one of the groups. The trajectory of collective representations goes from the definition of Israel as a problem to its absolute negation, passing through an emphasis on its artificial nature and the 'error' of its creation. The different social sectors emphasize different moments: from the conservative and more moderate-reflective sectors (Israel as problem), passing through the more centrist sectors of society ('error', 'artificial state'), to the more activist youth groups on the left (comparison to Nazi Germany).

Finally, we need to mention the role of denial in antisemitism, expressed in the condemnation of antisemitism while simultaneously entertaining an antisemitic discourse. The negation of antisemitism and the normalization of anti-Jewish hostility are at the same time basic components of the Spanish case. It would appear that hostility to and negative opinions about 'the Jews' operate in a sort of unreflective declaratory mode. They exist on a plane of normalcy. With nothing to snag their arguments, antisemitism is invisible to antisemites. Perhaps we could say that the antisemite is invisible to him- or herself. Antisemitic stereotypes somehow escape the politically correct ethical and integrative norms of universalism which AQ5 guide the treatment of other minorities in contemporary Spain.

\section{References}

Albiac, G. (2004) 'Meditar Jenin', in VVAA, En defensa de Israel, Zaragoza: Certeza.

AQz Alonso, L. E. (1998) La mirada cualitativa en sociología, Madrid: Fundamentos.

Assmann, J. (1992) Das Kulturelle Gedächtnis: Schrift, Erinnerung und Politische Identität in frühen Hochkulturen, München: C.H. Beck.

Alvarez Chillida, G. and Izquierdo, R. (eds) (2007) El antisemitismo en España, Cuenca, Ediciones Universidad Castilla-La Mancha.

Baer, A. (2011) 'The voids of Sefarad. The memory of the Holocaust in Spain', Journal of Spanish Cultural Studies 12(1): 95-120.

Baer, A. and López, P. (2007) 'El conflicto como caricatura. Israel en el humor gráfico español sobre la guerra del Líbano de 2006', Cuadernos de Analisis del Movimiento Contra la Intolerancia 30: 31-44. 


\section{EUROPEAN SOCIETIES}

Baer, A. and Schnettler, B. (2011) 'Holocaust-Erinnerungskultur als Wissensnetzwerk: Zwischen globaler Wertegemeinschaft und universaler Symbolkultur', Tagungsband des Fubiläumskongress der Deutschen Gesellschaft für Soziologie.

Beck, U. (2004) 'Entgrenzung der Intifada oder: Das Linienbus-Ticket nach Haifa', in D. Rabinovici, U. Speck and N. Sznaider (eds), Neuer Antisemitismus? Eine globale Debatte, Frankfurt am Main: Suhrkamp.

Cobo, F. and Ortega, M. T. (2008) La extrema derecha en la España contemporánea, Madrid: Asociación de Historia Contemporánea.

Culla, J. (2004) 'Encuentros y descuentros Hispano-Israelís: una perspectiva periférica', in R. Rein (ed.), España e Israel veinte años después, Madrid: Fundación Tres Culturas.

Finkielkraut, A. (2004) 'In the name of the Other: reflections on the coming anti-Semitism', Azure 18.

Gabriel, M. (2010) 'Medios de comunicación, judíos e Israel durante la operación Plomo Fundido', in VVAA, Israel en los medios de comunicación españoles (2000-2010). Entre el estereotipo y la difamación, Madrid: Hebraica ediciones.

Hervieu-Léger, D. (1993) La religion pour mémoire, Paris: Les Editions du Cerf.

Ibañez, J. (1979) Más allá de la sociología. El grupo de discusión: técnica y práctica, Madrid: Siglo XXI.

Lopez, A. (2007) 'La evolución de la prensa española con relación a Israel, AQ4 el antisemitismo y el conflicto arabe-israelo-palestino', in R. Rein (ed.), España e Israel, Madrid: Dykinson.

León Barrios, G. (2007) 'El grupo de discusión como artefacto científico para el análisis social', Revista Comunicologi@: indicios y conjeturas. Publicación Electrónica del Departamento de Comunicación de la Universidad Iberoamericana Ciudad de México, Primera Época, Número 7, primavera 2007.

Martin Criado, E. (1997) 'El grupo de discusión como situación social', Revista española de investigaciones sociológicas 79: 81-112.

Northrop, F. S. (1962) 'Foreword', in W. Heisenberg (ed.), Physics and Philosophy. The Revolution in Modern Science, New York: Harper \& Row. Ottolenghi, E. (2005) 'Europe's good Jews', Commentary December 2005. Pedrosa, M. (2007) 'El antisemitismo en la cultura popular española', in G. Alvarez Chillida and R. Izquierdo (eds), El antisemitismo en España, Cuenca: Ediciones Universidad Castilla-La Mancha.

Pollock, F. and Adorno, T. (2011) Group Experiment and Other Writings: The Frankfurt School on Public Opinion in Postwar Germany, Cambridge, MA: Harvard University Press.

Stallaert, C. (1998) Etnogénesis y etnicidad en España: una aproximación histórico-antropológica al casticismo, Barcelona: Proyecto A Ediciones. 
Villatoro, V. (2004) 'De qué hablamos cuando hablamos de Israel', in VVAA (ed.) En defensa de Israel, Zaragoza: Certeza, pp. 333-50.

Volkov, S. (2000) Antisemitismus als Kultureller Code, München: C.H. Beck.

Wahnón, S. (2005) 'El tratamiento mediático del conflicto palestino-israelí: “Antisionismo o nueva judeofobia?", in J. Israel Garzón, et al. (eds), El estigma imborrable. Reflexiones sobre el nuevo antisemitismo, Madrid: Hebraica Ediciones, pp. 21-45.

Alejandro Baer is Assistant Professor at the Chair of Sociology of Religion and Culture at the University of Bayreuth (Germany). His research is in the area of memory studies, antisemitism and qualitative research methods. $\mathrm{He}$ is author of the book Holocausto. Recuerdo y Representacion (Losada, 2006) and co-editor of España y el Holocausto (Hebraica, 2007).

Paula López is a sociologist. She has worked as public opinion and market research expert in several private and public institutions in Spain and was lecturer in social research methodology at the Universidad Pontifica de Salamanca and Universidad Complutense Madrid. She is co-author of Percepciones sociales sobre las personas mayores (Instituto de Migraciones y Servicios Sociales, 2002).

Address for correspondence: Alejandro Baer, E-mail: a.baer@uni-bayreuth.de 